\title{
Teaching An Electrical Circuits Course Using A Virtual Lab
}

\author{
Md Zahidur Rahman, LaGuardia Community College, USA
}

\begin{abstract}
This paper describes designing and implementing a scholarship of teaching and learning (SoTL) study in a basic electrical circuits course at LaGuardia Community College. Inspired by my understanding of Shulman's (2005) concept of "signature pedagogy" and Mazur's (2009) emphasis on student-centered approaches, and aware that our students did not always understand the electrical theory concepts presented in class, I decided to change my pedagogy. We explain our efforts to train our students to think as engineers, first by making them more "visible" and "accountable" in the classroom, and second, by offering them hands-on practice through the use of Multisim, a free and open source simulation software. The study presented here reports the effect that using Multisim had on our students' ability to learn and apply electrical theories and concepts. The implications for the teaching of the basic electrical circuit course are offered as well as my reflection on my own growth as a teacher and my developing understanding of the scholarship of teaching and learning.
\end{abstract}

Keywords: Multisim; Simulation; Software; Electrical Circuits

\section{INTRODUCTION}

hen I studied for my Bachelor of Science in Electrical Engineering at Bangladesh University of
Engineering and Technology (BUET), Dhaka, Bangladesh, in the early 1990s (1991-1996), most of the electrical engineering courses such as Electrical Circuits, Electronics, Electrical Machines, and Electrical Measurement and Instrumentation included a one- or two-credit laboratory course that complemented the three-credit lecture course focused on electrical theories and concepts. Instructors usually discussed theories and presented some problems and solutions; they also gave us problems to work on in class and circulated around the room as we worked independently. In the lab, we performed hands-on experiments to test and verify the theories and concepts we had learned in class. Working in groups of two or three students, we performed experiments using authentic electrical tools such as voltmeters, ammeters, multimeters, and rheostats to design, build, and test electrical circuits.

When I came to the United States in 1999 to continue my studies in engineering, I was surprised to find that professors primarily lectured and demonstrated solutions to problems on the blackboard, and did not provide many opportunities for the hands-on experimenting and independent problem-solving that I had experienced in Bangladesh. When I began to teach at City College, and later at LaGuardia Community College, I adopted the pedagogical approach I had encountered most frequently in the U.S. I lectured, stood at the blackboard, and wrote out the solutions to problems, stopping periodically to ask my students if they had any questions. They rarely did; so I assumed that they understood what I was doing. Occasionally, I would give students a problem to solve in class on their own. I walked around the room and observed them as they worked, but I did not interact with them very much.

Then, while participating in LaGuardia Community College's Carnegie Seminar on the Scholarship of Teaching and Learning, I came to think more deeply about my pedagogy and ways to improve students' learning. I had joined the seminar because I wanted to learn more about the scholarship of teaching and learning to improve my teaching. As we discussed the work of Lee Shulman (2005) on "signature pedagogies," I reflected upon my own experiences in Bangladesh and in the U.S. Shulman (2005) described a typical engineering class as follows. 
Although the teacher faces his class when he introduces the day's topic at the beginning of the session, soon he has turned to the blackboard, his back to the students. The focal point of the pedagogy is clearly mathematical representations of physical processes. He is furiously writing equations on the board, looking back over his shoulder in the direction of the students as he asks, of no one in particular, "Are you with me?" A couple of affirmative grunts are sufficient to encourage him to continue. (p. 53)

Shulman's (2005) description sounded a lot like both my experience as a student in the U.S. and the classes I was teaching, but I was no longer sure that it was an effective approach. Shulman also noted that in lecture-based teaching there is "almost no reference to the challenges of practice ... [and] little sense of the tension between knowing and doing" (p. 54). Shulman's critique of the typical engineering class helped me to see that I was not meeting the goal of preparing my students to be engineers who must not only understand theory and concepts, but also devise solutions to real-life problems, test their solutions, and troubleshoot those that do not work.

Furthermore, after viewing a video showing Eric Mazur (2009) engaging his Harvard students in the study of physics, I realized that I needed to change the dynamic in my classes. Instead of asking "Are you with me?" and turning back to the board while students passively watched me derive solutions to problems, I learned to build in more opportunities for them to solve problems themselves during our class sessions. Rather than simply observing as students work and waiting for them to ask me questions, I move around the class, crouching so I can see their work and understand where they are stuck, and ask questions that help them to discover the solution. Additionally, I call individual students up to the board as I sit among the others. I urge them not to be afraid to try; the other students and I will help them as needed. Using these methods, I can see clearly what confuses students and when they need help.

But, even with these changes, I believed that my pedagogy was not doing enough to prepare students for a career in engineering. Shulman (2005) wrote that "professional education is not education for understanding alone; it is preparation for accomplished and responsible practice in the service of others" (p. 53). In order to address my mission more fully, I needed to provide my classes with more hands-on experiences, similar to those I had had as an undergraduate student in Bangladesh. Unfortunately, at LaGuardia, one of the fundamental courses I teach, Electrical Circuits (MAE213), does not include a lab hour; students also do not have access to an equipped electrical engineering hardware lab. As a result, LaGuardia Engineering faculty are exploring simulation software (also known as "virtual labs") that engages students in realistic problem-solving activities requiring the application of theories and concepts learned in the classroom.

While not ideal, virtual labs offer many advantages including powerful processing and simulation facilities, ease of use, and accuracy. Where physical labs are not available, as is the case at LaGuardia, virtual labs can provide students with useful experience (Hackworth \& Stanley, 2001; Hall, 2000; Lee, Li, \& Cheung, 2002). Moure, Valdés, Salaverría, and Mandado (2004), Butz, Duarte, and Miller (2006), and Swayne (2012) all noted that virtual laboratories also have potential for helping students understand theoretical principles. When Kollõffel and De Jong (2013) studied groups of vocational engineering high school students to assess their understanding of electrical theories and concepts, they found that adding virtual lab experiences to the traditional lecture and hardware lab approach helped students learn theoretical concepts. They wrote that students might face some difficulties and need more time to construct, design, analyze, and verify the electrical circuits assignments using real labs while virtual labs enable students to perform these tasks more quickly, and they suggest that, in contrast to real labs, virtual labs are economical and can save time.

MATLAB and Multisim are the two simulation software packages in use at LaGuardia. Utilized for numerical computation and programming, MATLAB is a sophisticated and expensive software package often employed by professional electrical engineers. Multisim, on the other hand, is a free and comprehensive circuit analysis program that allows for the design, analysis, visualization, and simulation of electrical and electronic circuits. In addition to an extremely realistic interface, it allows students to use a mouse and graphics options to create schematic diagrams. Fraga, de Castro, Alves, and Franchin (2006) studied groups of college engineering students in an electrical circuits class. They used two computer simulation software programs, PSpice and Multisim, and found that Multisim provided students an environment closest to a real lab where they can use virtual oscilloscopes, multimeters, and ammeters to develop their knowledge of electrical behavior. 
With the Multisim software, students can engage in realistic problem solving; they can build simulated circuits, learn how to construct complex circuits with various components, and verify the circuit design. After building their simulated circuit, students "turn on the electricity" using Multisim's virtual "switch." With this last step, students can immediately see if the circuit they have designed will function as they planned. If it does not, they can continue working on the problem, and utilize their knowledge of electrical theories and concepts to troubleshoot design issues and create alternatives until they arrive at the correct solution to the problem.

At LaGuardia, Electrical Circuits, a three-credit course required for all civil, mechanical, or electrical engineering students, proved to be an ideal environment in which to begin exploring the pedagogical advantages of Multisim. The curriculum focuses on basic components of electrical theory and practice such as resistors, capacitors, and inductors, and reinforces fundamental mathematical and electrical concepts needed for designing and analyzing electrical circuits. Using Multisim allows students to put their knowledge of theory into practice using a realistic, albeit simulated, environment.

\section{METHODOLOGY}

In the informal study of my Spring 2013 Electrical Circuits course described below, I examined the extent to which Multisim helped 17 undergraduate students ( 15 male and 2 female students) solve engineering problems. Of the 17 students, 3 were Civil Engineering majors, 10 were Electrical Engineering majors, and 4 were Mechanical Engineering majors. I divided the students into two groups of equal size. For the first half of the semester, the students in Group 1 worked on one project, performing all calculations and solving all circuit design problems by hand without verifying their answers or testing their solutions with Multisim. Group 2 students worked on the same assignment, but used Multisim to verify the accuracy of their calculations and test the viability of their design solutions. In the second half of the semester, the groups switched: Group 1 completed two projects using Multisim, while Group 2 completed the same two projects without using Multisim. This arrangement assured that all students would experience solving problems both ways:

1. Using only hand calculations and hand-drawn circuit designs; and

2. Performing hand calculations, and then using Multisim to design, build, test, verify, and troubleshoot their solutions.

\section{RESULTS AND DISCUSSION}

As indicated in the project scores in Table 1, the median scores revealed that students who used Multisim did slightly better than students who did not.

Table 1: Project Scores: Hand Calculation or Multisim

\begin{tabular}{lcc}
\hline & Group 1 & Group 2 \\
& Median Score & Median Score \\
\hline Multisim & 91.5 & 91.5 \\
Hand Calculation Only & 88.5 & 89.0 \\
Percentage Increase & $3.4 \%$ & $2.8 \%$ \\
\hline
\end{tabular}

In an effort to get a better picture of students' interactions with the software, I also asked students to respond to these three questions at the end of the semester:

1. Which topics or projects were most difficult for you?

2. Which method (hand calculation only or hand calculations and Multisim verification) better reinforced electrical theory and concepts?

3. What assignments or activities were most effective?

Eleven students concurred that using Multisim was the most difficult part of the projects. Twelve students agreed that performing the assignments with the simulation software is a better way of reinforcing electrical theory and concepts, 3 students believed that performing hand calculations only is more effective, and 2 students thought 
there was no difference between the two. Clearly, the majority of the students considered the mixture of hand calculation and software simulation the most effective way to complete projects and homework assignments.

Both of the female students reported that using Multisim was the most difficult part of the class and noted that, for them, performing the hand calculations was more helpful in understanding electrical circuit theory and concepts, while the male students noted that Multisim provided a better way to understand the electrical theory and concepts of this course. This difference can potentially be ascribed to the assumption that males usually have more experience in dealing with various software tools and are not as intimidated by having to use software to simulate the circuit. However, with only two females in the sample, it is impossible to generalize this finding to all female students.

Although this experiment was conducted with a small sample of 17 students, the results suggest that students do indeed benefit from the use of Multisim. In short reflections at the end of their projects, students offered comments such as: "With the help of Multisim I was able to verify my answers and correct the one that I had wrong." "By doing this project I learned how to use Multisim to solve circuit problems, I also learned how beneficial it is to use Multisim. It is a very simple and quick way to check your answers for any mistakes."

\section{CONCLUSIONS}

Ideally, LaGuardia's engineering students would experiment with and test their solutions to electrical circuitry problems using authentic equipment in a well-furnished electrical engineering lab such as the one I used in Bangladesh. Lacking that possibility, based on the results of my Spring 2013 experiment, I believe that Multisim offers a next-best solution to the problem of providing students access to realistic environments in which they can test their solutions. Giving students this needed hands-on experience brings me closer to what should be a principal component of the signature pedagogy of engineering, and addresses Shulman's (2005) reminders about the importance of preparing students for their professional lives. In future semesters, I hope to continue my efforts to analyze and report upon the effect of using Multisim to help students master electrical engineering theories and concepts.

\section{AUTHOR INFORMATION}

Dr. Md Zahidur Rahman received M.E. and Ph.D in Electrical Engineering from the City University of New York Graduate Center. Currently, Dr. Rahman is an associate professor in the Department of Mathematics, Engineering and Computer Science at LaGuardia Community College and registered Professional Engineer in the states of New York and Michigan. Dr. Rahman received a NASA grant, Professional Staff Congress at the City University of New York (PSC-CUNY) grant and received a University Fellowship. His research interests are in environmental engineering, satellite remote sensing and its application, and alternative renewable energy. In the past 6 years, he has authored or co-authored more than 7 international conference papers.

\section{REFERENCES}

1. Butz, B. P., Duarte, M., \& Miller, S. M. (2006). An intelligent tutoring system for circuit analysis. IEEE Transactions on Education, 49(2), 216-223.

2. Fraga, J. R. C. P., de Castro, M. C. Alves, A. F., \& Franchin, M. N. (2006, September). Using simulation programs to enhance learning electrical circuits classes. Paper presented at COBENGE: Congresso Brasileiro de Educa..o em Engenharia [= 34th Brazilian Congress on Engineering Education], Universidade de Passo Fundo, Brazil. Retrieved from http://www.abenge.org.br/CobengeAnteriores/2006/ artigos/1_298_218.pdf

3. Hackworth, J. R., \& Stanley, W. D. (2001, June). An upper-division virtual laboratory in linear electronics. Paper presented at the American Society for Engineering Education Annual Conference \& Exposition, Albuquerque, NM, Session 2247. Retrieved from http:// search. asee.org/search/fetch?url=file $\% 3 \mathrm{~A} \% 2 \mathrm{~F} \% 2 \mathrm{Flocalhost} \% 2 \mathrm{FE} \% 3 \mathrm{~A}$ $\% 2 \mathrm{Fsearch} \% 2 \mathrm{Fconference} \% 2 \mathrm{~F} 25 \% 2 \mathrm{FAC} \% 25202001 \mathrm{Paper} 1121 . \mathrm{PDF} \&$ index $=$ conference_papers\&space= $129746797203605791716676178 \&$ type $=$ application $\% 2$ Fpdf\&charset $=$ 
4. Hall, T. M. (2000, June). Using simulation software for electronics engineering technology laboratory instruction. Paper presented at the American Society for Engineering Education Annual Conference \& Exposition, St. Louis, MO, Session 3547. Retrieved from http:// search.asee.org/search/fetch?url=file $\% 3 \mathrm{~A} \% 2 \mathrm{~F} \% 2$ Flocalhost $\% 2 \mathrm{FE} \%$ $3 \mathrm{~A} \% 2 \mathrm{Fsearch} \% 2 \mathrm{Fconference} \% 2 \mathrm{~F} 24 \% 2 \mathrm{FAC} \% 25202000$ Paper675.pdf\&index $=$ conference_papers\&space= $129746797203605791716676178 \&$ type $=$ application\%2Fpdf\&charset $=$

5. Kollõffel, B., \& De Jong, T.. (2013). Conceptual understanding of electrical circuits in secondary vocational engineering education: Combining traditional instruction with inquiry learning in a virtual lab. Journal of Engineering Education, 102(3), 375-393. doi:10.1002/jee.20022

6. Lee, W. B., Li, J. G. and Cheung, C. F. (2002). Development of a virtual training workshop in ultraprecision machining. International Journal of Engineering Education, 18(5), 584-596. Retrieved from http:// www.ijee.ie/articles/Vol18-5/IJEE1310.pdf

7. Mazur, E. (2009, November). Confessions of a converted lecturer. [Video file]. Retrieved from $\mathrm{http} / / / \mathrm{www}$. youtube.com/ watch?v=WwslBPj8GgI

8. Moure, M. J., Valdés, M. D., Salaverría, A., \& Mandado, E. (2004). Virtual laboratory as a tool to improve the effectiveness of actual laboratories. International Journal of Engineering Education, 20(2), 188-192. Retrieved from http://www.ijee.ie/articles/Vol20-2/IJEE1484.pdf

9. Shulman, L.. S. (2005). Signature pedagogies in the professions. Daedalus. 134(3), 52-59. Retrieved from http://www.jstor.org/stable/20027998

10. Swayne, K. (2012, April). An electrical circuits hybrid course model. Paper presented at the American Society for Engineering Education Southeastern Section Annual Conference, Starkville, MS, Session 572. Abstract retrieved from http://se.asee.org/proceedings/ASEE2012/ BoA2012ForProceedings.pdf 
NOTES 